\title{
7 An Unrealized Project: The Myra Lycia Affair
}

No other saint was more highly esteemed in Russia than St. Nicolas of Myra. The Christianization of Myra in Lycia was completed by 325; St. Nicolas was its bishop. He died in 330 and was buried in the church of Lower Myra. ${ }^{395}$ The Byzantine period saw mass pilgrimage to the shrine of St. Nicolas. Later, in 1087, after its conquest by the Seljuks, Italian merchants stole the relics and transferred them to Bari in eastern Italy, where they can still be seen.

After the Ottoman conquest, the Myra church went to rack and ruin. In 1850 it was visited by the famous Russian traveler and writer Andrei Nikolaevich Muraviev. He was moved by the poor state of the church and asked Metropolitan Filaret Drozdov for permission to restore it. ${ }^{396}$ With Filaret's help Muraviev collected 25,000 rubles and through the Russian vice-consul to Rhodes, H. Ducci, bought what was left of the church and the surrounding 42 hectares. The deal was concluded on behalf of Dimitris Antonas, an inhabitant of nearby Castelorizo. The purchase was effected with the help of the Metropolitan of Pisidia, Meletios; the sultan's firman allowing the restoration was issued in 1852. ${ }^{397}$ (During recent excavation of the territory of the church, Professor S. Otuken found a stone with a troparion to St. Nicolas in Slavonic and an inscription “Constructed by pious Russians 1853".). $)^{398}$

The restoration work continued in 1858, first by the local inhabitants and later by the architect Salzmann, who was in charge of the excavations and restoration from October 1858 to May 1860. He removed the soil from the church and uncovered the mosaic floors in the altar area. Due to lack of time and money only the main area of the church was restored. The work, costing about 40,000 rubles, was finished by 1863.

Though initial permission from the Pisidian metropolitan had been given, a patriarchal act of August 1858 ordered the Metropolitan of Pisidia to immediately stop all construction work, as the Greeks feared that they would lose control of the church

395 The first basilica in this place was built in the $5^{\text {th }}$ or $6^{\text {th }}$ century. The present day church with a crypt is dated to $8^{\text {th }}$ century. The church was rebuilt many times, but the altar area has been preserved while the walls are covered with frescoes from different periods. The exact burial place of St. Nicolas is unknown; the legendary sarcophagus, which is thought to be his, is dated 160-170 c.e. and is one of the many sarcophagi that survive in the church from a late Roman cemetery. See: R. M. Harrison, "Churches and Chapels of Central Lycia”, Anatolian Studies, 13 (1963); J. Borchhardt, ed., Myra: eine Lykische Metropole in antiker and byzantinischer Zeit (Berlin, 1975); S. Yildiz-Otuken, "Die Nikolaoskirche in Myra in Licht der neuester Forschungen”, Fremde Zeiten: Festschrift für Jurgen Borhardt, II (Vien, 1996): 227-238; Eadem, “Demre-Myra”, American Journal of Archaeology 1 (Boston, 1997).

396 Pribavlenija $k$ izdaniju tvorenij Sv. Otcov v russkom perevode, IX (=Mirlikijskaja tserkov’ i grobnica Sviatitelia Nikolaja Chudotvorca) (Moscow, 1850).

397 E. Sokolovskii, Otkrytie i vozobnovlenie drevnej basiliki Sv. Nicolaja v Mirach Likijskich (St. Petersburg, 1861).

398 Chr. Kalaitzis, Metropolitan of Myra, Ta Myrovola Myra. I istoria ton Myron apo ton 190 aiona os to 1922 (Athens, 2002), 196. 
and its surrounding lands. ${ }^{399}$ Subsequent patriarchal acts were, however, positive. For example, on September 16, 1859 Patriarch Cyril VII praised the zeal of Metropoli$\tan$ Meletios and the diligence of Dimitris Antonas. ${ }^{400}$ However, fears about Russian activities were not entirely quelled. In 1865 Patriarch Sophrony III sent a letter to the Pisidian metropolitan, Cesarios, asking for information concerning the church in Myra, whether the priest there had been commemorating the name of the Patriarch, and by whom he had been appointed. ${ }^{401}$ Clearly, the patriarch had received information about Russian activities which raised his suspicions.

In $1864 \mathrm{~A}$. N. Muraviev handed over the rights for the Myra land and the church to Ignatiev, who had just been appointed Russian ambassador to the sublime porte. According to Ottoman law, foreign subjects could not acquire land on Turkish soil, and that is why the land had been registered initially in the name of Antonas. The latter died in a shipwreck and his property was left to his sons. Ignatiev first entrusted the church in Myra to the Metropolitan of Rhodes, Dorotheos, and then made over the rights of the property to his mother-in-law, Duchess Anna Golitsyna. Antonas's sons received a compensation of 7,000 Turkish liras..$^{402}$

In $1870 \mathrm{H}$. Ducci was replaced by another Russian vice-consul to Rhodes, V. O. Jugovich. He received the title of ownership of the plot in Myra on behalf of A. Golitsyna; the land was described as erazi-i-emirije, i.e., it was to be cultivated for three years, otherwise it would revert to the government. ${ }^{403}$ In 1868 Ignatiev asked Makarii Sushkin, the abbot of the Russian monastery, St. Panteleimon on Mt. Athos to take care of the church and to send some monks to it. In this way a Russian monastery in Myra would be founded. St. Panteleimon Monastery agreed but without enthusiasm; it could see no benefit in acquiring the place and was afraid of a confrontation with the patriarchate. Nevertheless, Makarii sent two monks who settled near the church. They asked the ambassador for permission to collect aid in Russia. Permission was given by the Russian Synod when it met December, 1874 to January 1875. The two monks, Afanasii and Varsanofii, started collecting donations in 1877, just before the beginning of the Russo-Turkish War. In April 1878 they requested a renewal of permission, because they had been unsuccessful in their first attempt; but it appears they did not receive it. ${ }^{404}$

399 AKP KPA, cod. 32, No. 1858: 256-257 (See the edition of the text: Chr. Kalaitzis, Ta Myrovola Myra, 89-90).

400 AKP KPA, cod. 32, No. 1859: 472.

401 Chr. Kalaitzis, Ta Myrovola Myra, 66-67.

402 G. P. Begleri to V. N. Chitrovo, November 6, 1893, Rossija i Prvoslavnyj Vostok, 271.

403 N. N. Lisovoi, Russkoe duchovnoe i politicheskoe prisutstvie v Sviatoj Zemle i na Blizhnem Vostoke v XIX-nachale XX v. (Moscow, “Indrik”, 2006): 275; A. Heidborn, Manuel de droit public et administrative de l' Empire Ottoman (Vien, Leipzig, 1908), 327-332.

404 See a copy of this document in the archive of N. P. Ignatiev, GARF, f. 730, op. 1, d. 1150, 1. 1-1v. 
Before the beginning of the war, in 1876, Mt. Athos monks started collecting funds through St. Alexander Chapel in St. Petersburg. It was founded in memory of the attempt on Alexander II's life on May 25, 1867, but had remained unfinished. The donors had no difficulty in transferring their gifts to the Mt. Athos monks, so the chapel was dedicated to the church in Myra and sanctified in $1879 .{ }^{405}$ Money started coming in, and by January 1, 1896 the capital of the chapel for building a Russian monastery in Myra totaled 118,000 rubles.

At the beginning of 1876 the inhabitants of Myra sent the patriarchate a complaint about George Antonas (son of Dimitris) who did not allow them to pray in the church. The patriarch asked the Metropolitan of Rhodes to investigate the case. ${ }^{406}$ In a letter of the patriarch to Ignatiev (June 5,1877 ) we read that vice-consul Jugovich bought the land around the church and tried to force the inhabitants to leave their houses and rebuild elsewhere. When they refused, he did not allow them to attend church services. ${ }^{407}$

This letter was in fact the first official protest from the patriarchate. Why was it filed so late? One reason is that the Greeks had previously intended to restore the church with Russian help knowing that later it would inevitably pass into the hands of the patriarchate but that they had no definite plans of how this would happen. The presence of Mt. Athos monks and the attempts of Jugovich to legalize it as a Russian possession of course provoked anxiety. But the real struggle took place after 1878 when Ignatiev had already left Constantinople. In May 1878 the Greek vice-consul to Antalya addressed a letter to the great protosyggel of the patriarchate, stressing that if Russian activities were not immediately stopped, the Russians would establish a powerful monastery in the place and use it "as a stronghold of pan-Slavic aims". ${ }^{408}$ The same year, Joachim III again protested, this time to Ambassador Lobanov-Rostovskii. In the protest, the patriarch repeated the complaint he had made to Ignatiev. In 1879 Joachim reported to the Synod that the patriarchate demanded a takrir to halt the sale of the land. On August 4, 1879 a sultan's teskere was issued, stating that the restoration of the church by Muraviev had been an act of piety and the church should be made subordinate to the patriarchate. The sultan's government was to ensure that the land would not be passed out of the hands of the patriarchate and in the future no threats would be made towards the local inhabitants. ${ }^{409}$ After the publication of the governmental document a monk from the patriarchate was sent to Myra to work in

405 See the documentation of the chapel: AVPRI, f. 337/2 (Russian Imperial Palestine Society), op. 873/13, d. 13 (1877-1918).

406 Chr. Kalaitzis, Ta Myrovola Myra, 197.

407 AKP KPA, cod. 47, No. 2869: 190-191. See the edition of the text: Chr. Kalaitzis, Ta Myrovola Myra, 68-69.

408 Ibid., 69, 197-198.

409 See the full text in Russian translation in: L. A. Gerd, ed., Rossia i Pravoslavnyj Vostok: 309; extracts are edited in: Chr. Kalaitzis, Ta Myrovola Myra, 70. 
the church and organize a school. His activities were, however, misunderstood by the sons of Antonas, who refused to give him the holy vessels and other church property. Nothing could be done by the next abbot, Eugenios, appointed in 1881. In 1884 the Metropolitan of Rhodes Germanos (future Patriarch, 1912-1918) sent by the patriarch, tried to resolve the conflict. He reported that the Russians were planning to open a consulate in Myra-though not with the intent to protect their acquired properties. In 1885 Germanos was appointed patriarchal exarch to Myra and made efforts to establish the rights of the patriarchate to the church. ${ }^{410}$

However, a Russian consul to Myra was not appointed, and in November 1886 Ignatiev passed the title of the properties in Myra to Grand Duke Sergei Alexandrovich, head of the imperial Orthodox Palestine Society. Mundane matters were entrusted to Jugovich, then vice-consul to the Dardanelles. Meanwhile on June 25, 1886 a new abbot was sent to Myra, a local person, Paisios from Kastelorizo. By this appointment Metropolitan Germanos hoped to establish closer contact with the inhabitants of the village.

Further events can be reconstructed from the correspondence of Abbot Paisios with Metropolitan Venedictos and the reports of Jugovich. Following the instructions received from the Palestine Society, Jugovich had to receive permission from the patriarch for construction of a Russian church in Myra in compliance with the Salzmann plan, and for settling Russian monks there. He entrusted the matter in Constantinople to the advocate, G. Apostolidis. Apostolidis's job was to acquire a patriarchal sigillion (act), which would allow Russia to gain possession of the monastery for a limited period. The church would be given to the Russians for 50-60 years but with conditions. They had to pay the patriarchate a rent of 500 francs for the first three years; 1,000 francs the next ten years; 5,000 francs for the remaining years. The contract had to be bought for a sum of 160,000 francs $(30,000$ of them allotted to the schools of the patriarchate). In addition to the contractual costs, the advocate would cost 4,500 francs regardless of the outcome. ${ }^{411}$ The conditions were considered too demanding given the probable outcome and the Society decided to reject them and only give Jugovich the task of legalizing the estate as the Russian purchase of the church had never been officially recognized by either the Greeks or the Ottomans. It was thought that if the Ottomans officially confirmed the purchase, the patriarchate would concede the church on more suitable terms. If the Ottomans refused, the patriarchal act would be of no use any way.

In June 1887 Jugovich went to Myra to assure himself that the land was still regarded by the Ottoman authorities as a Russian possession. He registered the prop-

410 G. Papadopoulou, i syghronos ierarchia tis Orthodoxou Anatolikis Ekklisias I (Athens, 1895), 454455; Chr. Kalaitzis, Ta Myrovola Myra, 198, 200.

411 N. N. Lisovoi, Russkoe duchovnoe i politicheskoe prisutstvie v Sviatoj Zemle i na Blizhnem Vostoke, 277-278. 
erty on behalf of M. P. Stepanov and received 25,000 francs from the capital of Myra for his expenses. The local Ottoman authorities reaffirmed the rights of Duchess Golitsyna and the Russians to the land. The Greek abbot Paisios reported on the visit of Jugovich to the patriarchate in a very critical manner. The Russian and French consuls to Rhodes who accompanied Jugovich clearly intended to deprive the Greeks of the Church of St. Nicolas, he wrote. ${ }^{412}$ In all of this the Russian embassy in Constantinople remained silent. The lack of interest on the part of the embassy was the result of the personal negative attitude of Ambassador Nelidov towards the Palestine Society, and by his belief that a successful outcome was not possible.

After the departure of Jugovich, the Greek clergy did its best to persuade the Ottoman authorities to take decisions that were unfavourable to Russia, which it did, for example, the governor of Antalya stated that the Myra estates were of strategic importance for Turkey. That is why the documents presented by Jugovich for approval to the department and the erazi-i-emirije were put aside pending further investigation by the War Ministry. Thus the affair changed from being purely an ecclesiastical one to being a political one. ${ }^{413}$

The Ottoman government sent two commissions to Myra. The first was headed by topography engineer, Lieutenant Colonel Abdulla-Bey; it went to Myra in November 1889 and returned to Constantinople in March 1890. The commission first made a survey of all monastic and non-monastic lands in the region and, second, interrogated the locals in order to know how Jugovich had acquired the land and what his legal status was regarding this land. ${ }^{414}$ The Ottoman commission was followed by a patriarchal one, consisting of three metropolitans and several laics. The abbot of Myra was also summoned to Constantinople to report. The entire affair of the acquisition of the land by Anna Golitsyna and the mission of Jugovich were again repeated. The final conclusion of the commission was reflected in the Synod Act of March 22, 1890. The patriarchate sent a decisive protest to the porte countering the demands of Jugovich. He asked that the Ottoman government issue an official act, confirming the inviolability of the church property in Myra. ${ }^{415}$ However, owing to the measures undertaken by Jugovich in Constantinople, the Ottoman general headquarters denied that the Myra estate was of any strategic importance. Nevertheless, no final decision on the affair was taken.

412 G. P. Begleri to V. N. Chitrovo, November 6, 1893, L. A. Gerd, ed., Rossia i Pravoslavnyj Vostok, 269-270.

413 N. N. Lisovoi, Russkoe duchovnoe i politicheskoe prisutstvie v Sviatoj Zemle i na Blizhnem Vostoke, 278-279; L. A. Gerd, Constantinopol' i Peterburg, 379-380.

414 G. P. Begleri to V. N. Chitrovo, November 6, 1893, L. A. Gerd, ed., Rossia i Pravoslavnyj Vostok, 270-271.

415 AKP KPA, cod. 60, prot. 1242: 70; G. P. Begleri to V. N. Chitrovo, November 6, 1893, L. A. Gerd, ed., Rossija i Pravoslavnyj Vostok, 270. 
Jugovich then insisted on sending a new Ottoman commission to Myra. His request was granted, and in 1891 a new commission of three officers was sent, along with Jugovich. At the same time the Metropolitan of Pisidia was told to prevent any interference of the Turkish officials in church affairs and to report any steps of the governmental commission to the patriarchate. ${ }^{416}$ The correspondence of the Metropolitan of Pisidia, the Abbot of Myra and the patriarchate in the years 1891-1893 reflects the struggle between the church and the Russian representatives, both parties trying to convince the Ottoman government of the rightness of their cause. ${ }^{417}$

Jugovich died in 1893. The Palestine Society appointed Begleri, the agent of the Russian Shipping and Trade Company in Constantinople, in his place (in May or June 1893). Some of the hopes pinned on him no doubt arose because of his close relations with Patriarch Neophytos VIII (1891-1894). V. N. Khitrovo, secretary of the Palestine Society, expected Begleri to accomplish two tasks: 1) gather information on the case from the patriarchal archive; 2) negotiate with the patriarch on the case and convince him to come up with a good solution in exchange for a certain sum of money.

Begleri's plan of actions was to convince Patriarch Neophytos VIII to help the Russians. If the Ottomans got involved in the affair, a rumor would be spread that the monastery would be turned into a nunnery, and any suspicions that the monastery would be used for political or military purposes would thus be neutralized. ${ }^{418}$ Begleri first met with the patriarch to deal with assistance to Russia at the beginning of October 1893. He hoped to reach a positive resolution, based, firstly, on the Russophile disposition of Neophytos VIII, and secondly, on the fact that the monastery in Myra brought in no income to the patriarchate, but, on the contrary, created many difficulties.

The next meeting of Begleri with the patriarch took place at the end of October 1893. The patriarch informed Begleri that the first secretary of the Synod had already gathered the documentation on the case, and that the members of the Synod were very hostile towards the Russians and their activities in Myra, because Jugovich's actions had resulted in the involvement of the Ottoman government. Nevertheless, Neophytos promised to do his best and to call the Metropolitan of Pisidia, Benedictos, to Constantinople and discuss the matter with him. However, Begleri found it very difficult to resolve the matter as it stood because it had been complicated by becoming political.

In February 1894 Begleri informed Professor Troitskii that the former Metropolitan of Pisidia, Benedictos, had written an explanation of the issue of Myra. The patri-

416 Ibid., 271; Session of the Patriarchal Synod February 26, 1891. See: Chr. Kalaitzis, Ta Myrovola Myra, 202.

417 Ibid., 202-203.

418 G. P. Begleri to V. N. Khitrovo, November 6, 1893, L. A. Gerd, ed., Rossija i Pravoslavnyj Vostok, 267-278. 
arch, in his opinion, wanted to receive a guarantee of support from the Russian government in the event that he hand over the monastery to the Russians. ${ }^{419}$ In April 1894 Begleri visited St. Petersburg and met the secretary of the Palestine Society, V. N. Khitrovo. One cannot doubt that their topic of conversation was the Myra affair. The leaders of the Palestine Society, however, were pessimistic about the matter. Begleri proposed another solution: that the church would be restored with Russian money, and the keys would be handed over to the patriarch on the condition that there would be patriarchal permission for a church service in Slavonic for the Russian pilgrims. Begleri's proposal was as a whole adopted by Khitrovo, however, it was rejected in Moscow. Ambassador Nelidov in Constantinople also thought it a good solution and the only possible way out at that moment. ${ }^{420}$

Further events in Constantinople (the earthquake in summer 1894, the struggle of the patriarch against the porte and the members of the synod, and the abdication of Neophytos VIII) hindered a resolution of the Myra affair. During the reign of Patriarch Anthimos VII, Begleri proposed further action to Troitskii. ${ }^{421}$ We don't know whether he received permission or not, but a year later he reported the existence of a letter from the Metropolitan of Pisidia to the patriarchate (May 4, 1896) on the same subject. According to the letter, the kaimakam of Antalya, on arriving in Myra, had called together all the inhabitants and told them that they had no right to sell their estates. The land, he said, had never belonged to the church, but to Duchess Golitsyna and was now up for public sale. ${ }^{422}$ In Begleri's opinion, the Ottoman government wanted in this way to reaffirm its possession of the land. He devised another plan, namely to send the porte a note about the Russian tsar's patronage of this place. One has to suppose that this note was never sent, and no trace of it is found among Begleri's letters to Troitskii. Patriarch Constantinos V, when asked about the affair, paraphrased Virgil's famous words "I am afraid of the Russians even when they are bringing gifts". ${ }^{423}$

After the removal of the Russians from Myra, the situation did not improve for the Greeks. The correspondence between the abbot of Myra and the patriarch in 1897 and 1898 reveals tense relations with the locals and the presence of large debts of the church. ${ }^{424}$

Ignatiev remained interested in Myra till the end of his life. On July 9, 1908 he asked M. P. Stepanov about the situation. Not seeing a favourable outcome, the Palestine Society decided to hand over the Myra-Lycian capital to the Bargrad commit-

419 Ibid., 298.

420 G. P. Begleri to I. E. Troitsky, June 10, 1894, ibid., 304-306.

421 G. P. Begleri to I. E. Troitsky, March 19, 1895, ibid., 339.

422 G. P. Begleri to I. E. Troitsky, May 23, 1896, ibid., 358-359.

423 A paraphrase of “Timeo Danaos et dora ferentes” from The Eneid by Virgil.

424 AKP KPA, cod. 69 (17 April 1897), prot. 947, 84; ibid., cod. 70 (November 7, 1898), prot. 5857, 395. 
tee, who was erecting a Russian church in Bari. The Russian ambassador to Constantinople, Charykov, supported this move and stressed that the military and political considerations which had previously guided the thinking of the Russian government, were no longer relevant, and the construction of a magnificent church in Myra would no longer give Russia its accustomed moral status. On December 7, 1910 the capital was finally handed over to the Bargrad committee..$^{425}$

So, despite the enormous sums wasted on resolving the affair and all the efforts of the diplomats and agents, the plan to create another Russian monastic center in the diocese of the Patriarchate of Constantinople failed. Mt. Athos remained the only stronghold of Russian monasticism in the east Mediterranean up to 1917.

425 M. P. Stepanov to N. F. Geiden, AVPRI, f. Embassy in Constantinople, op. 517/2, d. 7683, 1. 27-32v; N. V. Charykov to A. A. Shirinskiy-Shichmatov, November 10, 1910, ibid. 